\title{
Development prospects of the oil crops' market and products of their processing in the Krasnoyarsk Krai
}

\author{
N.I. Pyzhikova, V.L. Bopp*, and T.G. Sheremetova \\ Krasnoyarsk State Agrarian University, Krasnoyarsk, Russia
}

\begin{abstract}
Over the past few years, oil crops cultivation has become investment-attractive in our country. This is due to both the increase in demand for products of their processing in domestic and foreign markets and the sustainable development of the processing and food industry. This article reviews approaches to the formation of the technologies introduction system for growing oil crops in Central Siberia (rape, dodder, mustard), industrial production of oils, food additives and feed products from them using biotechnology techniques, with a view to creating a hightech competitive export-oriented oil sector of the agro-industrial complex in Krasnoyarsk Krai, which creates added value and increases its investment attractiveness.
\end{abstract}

\section{Introduction}

One of the main development vectors of the Krasnoyarsk Krai economy is the creation of a high-tech agro-industrial complex based on new innovative technologies, allowing to obtain regional products with high added value. The fat-and-oil sector of the regional agro industrial complex is becoming a dynamic agribusiness sector, owing to the increasing role in the food, pharmaceutical industries, animal husbandry and poultry breeding.

Statistics of recent years testify to the crop growers' success of the Krasnoyarsk Krai. The annual gross harvest of grain crops in the amount of 2 million tons has brought the region among the leaders of the SFD in this indicator [1]. According to Rosstat in 2019, the Krasnoyarsk Krai showed positive dynamics in terms of such indicators as the gross oil crops harvest, their yield and acreage, and to produce rape oilseeds, Krasnoyarsk Krai became the first in the country. Thus, in 2019, the gross oilseeds harvest in the region amounted to 191,7 thousand tons $(126.3 \%$ by 2018 , or $+39,9$ thousand tons), including rape seeds $-182,7$ thousand tons $(123.1 \%$ by 2018 , or $+34,3$ thousand tons) with a yield of $14.6 \mathrm{cwt} / \mathrm{ha}(101.4 \%$ by 2018 , or $+0.2 \mathrm{cwt} / \mathrm{ha}) .154,9$ thousand hectares $(131.3 \%$ by 2018 , or $+36,9$ thousand hectares) were allocated for these crops' sowing [2].

According to the regional industrial ministry, the oil crops cultivation in the region is mainly occupied by agricultural organizations and their number is growing every year, a total of about 200 manufacturers are registered in this activity scope.

\footnotetext{
* Corresponding author: info@kgau.ru
} 
Increasing interest to oil crops gave an impetus to increase acreage in the region, while many plant-growers decided to cultivate crops which are new to them: rape, dodder, soybeans. The share of oil crops in the total structure of the agricultural crops' sowing area of the region increased by almost a third in 2019 compared to 2018 [3].

At the same time, oil crops processing in the region is not developed enough to date. The Center of regional agroanalytics named only one line for the rapeseed oil production, where 9 thousand tons per year are produced. In this regard, a significant part of the oilseed harvest is sold outside the region (mainly to other regions of the country and partly abroad).

Considering that the Krasnoyarsk Krai has all the natural and climatic resources, research, labor potential required to consolidate the positive dynamics of oil crops production development, introduction of innovative technologies of their deep processing will allow the region to take a decent place among producers in this industry and ensure products' competitiveness in domestic and foreign markets.

In 2018, Krasnoyarsk State Agrarian University together with its long-term industrial partner LLC "OPH Solyanskoye" LLC won the competition held by The Ministry of Education and Science of the Russian Federation according to the Federal Government Resolution No. 218 among the organizations offering complex projects' implementation for the creation of high-tech production.

The Krasnoyarsk project involves the creation of complex high-tech production of vegetable oil crops raw material and products of its processing in Siberia (further referred to as - the Project) based on using both natural factors and modern advances in agricultural biotechnology and original deep processing developments.

The aim of the Project is to substantiate approaches and implement high-tech, efficient, waste-free, environmentally friendly ways of producing vegetable oils, food additives and forage products from oil crops of the Siberian region, which will provide the population of the region with high-quality and safe food.

Tasks:

1. Development, approbation, and implementation of oil crops cultivation technologies of rape, dodder, mustard,

2. Development, approbation, and introduction of oil extraction methods from rape seeds, dodder, mustard by cold pressed extrusion method.

3. Development of technologies for obtaining highly valuable special products from oil production waste.

\section{Materials and Methods}

In the process of research, methods of comparative analysis, abstract-logical, statisticaleconomic, calculation-constructive methods were used. The research was carried out using data from the Federal State Statistics Service of the Russian Federation, the Federal Customs Service, the information of the Internet resource "Export of regions of Russia" of the Russian export center.

\section{Results and discussion}

The project to create high-tech production for cultivationand deep processing of oil crops on the Krasnoyarsk Krai territory was developed in cooperation with LLC "OPH" Solyanskoye".

At the first stage of the Project's realization, scientists of Krasnoyarsk SAU developed optimal agrotechnologies of oil crops' cultivation (rape, dodder, mustard). The introduction of research results on the production fields of "Solyanskoye" OPH allowed to increase the 
rape yield in the enterprise in 2019 by 2 times, in 2020 - 3 times. Developed cultivation technologies are ready for replication in farms of the region.

An important stage in the implementation of the Project was the research to improve existing and search for innovative ways of extracting oils from rape, dodder, mustard seeds $[4,5]$. As a result of the research, extrusion - press method of cold pressing was proposed. This is the so-called enzymatic bioconversion of polysaccharides and (partially) proteins through the use of low temperature microorganisms' strains, followed by cold pressing or extrusion-pressing method of processing.

The obtained products of oil crops processing will be used in the food industry in the form of oils or lecithin, as well as in the form of protein composite dry mixtures and extruded granular feed products in livestock and poultry farming.

For practical implementation of innovative oil crops deep processing technologies, scientists of the University have improved and, in some cases, developed new universal equipment of oil crops raw materials' processing- All developments are protected by patents of the Russian Federation.

The proposed technology was developed for the first time considering the best world analogues and domestic experience of oil crops grains' deep processing. The product complies with the current requirements of the state standards of industrial oil raw material ' processing from rape, dodder, mustard, soybean; produced food products fully comply with the requirements of technical regulations of the Customs Union for oil-and-fat products.

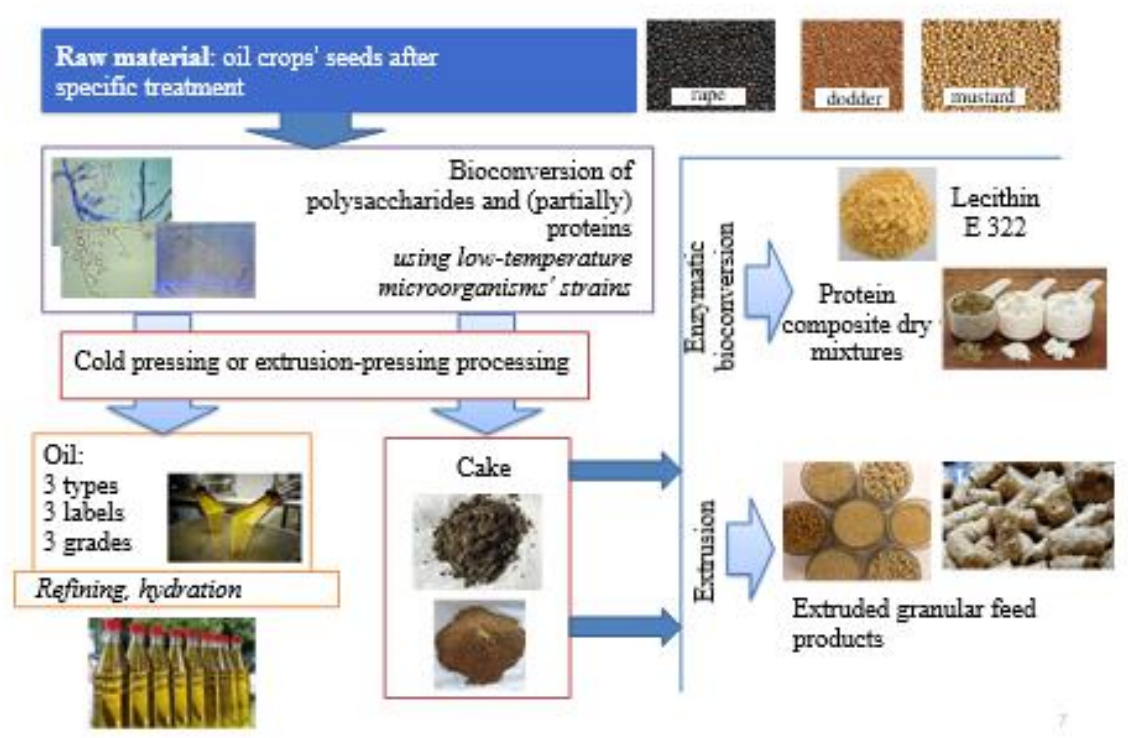

Fig. 1. Unique technologies - unique products.

This comprehensive system of deep oil crops grains' processing using biotechnology, freezedrying, extrusion processing allows to achieve an increased quantity and quality of the products being developed. The use of seeds grown in local Siberian conditions provides high productivity of plants and efficiency of industrial oilseeds' processing.

The main advantage of the product compared to analogues is the sales price reduction by $8-10$ percent. Since production is planned on the territory of the Krasnoyarsk Krai, transport costs are reduced at least twice relative to similar foreign products. 
The Project is currently under way to completion. Technologies of scientists of Krasnoyarsk SAU have passed all necessary procedures for introduction into production, and this year in the fields of LLC "OPH Solyanskoye" it is planned to launch a full-scale creamery with a capacity of 9 thousand tons of oil products per year.

Potential consumers of the final product are agricultural enterprises of various forms of ownership. A separate category of consumers is the enterprises of the food industry, where the created products are used in the production of bakery, pasta, confectionery products, as well as in the production of light snacks, cereals, meat emulsions. The production of the product is able to satisfy the demands of both large-commodity production and small market participants, including various fodder, food, pharmaceutical enterprises [6].

Within the framework of the project, marketing works of checking supply and demand for oil seeds, oils, cake, including in foreign markets [7] were carried out. The analysis results of trends in the oil-and-fat industry development, the oil crops market and products from them showed that this sector of crop production and its processing products is promising for the Krasnoyarsk Krai. The most cost-effective is the rape production. Dynamics of individual indicators of rape production economic efficiency in agricultural organizations of the Krasnoyarsk Krai for several recent years is shown in figures 2 and 3.

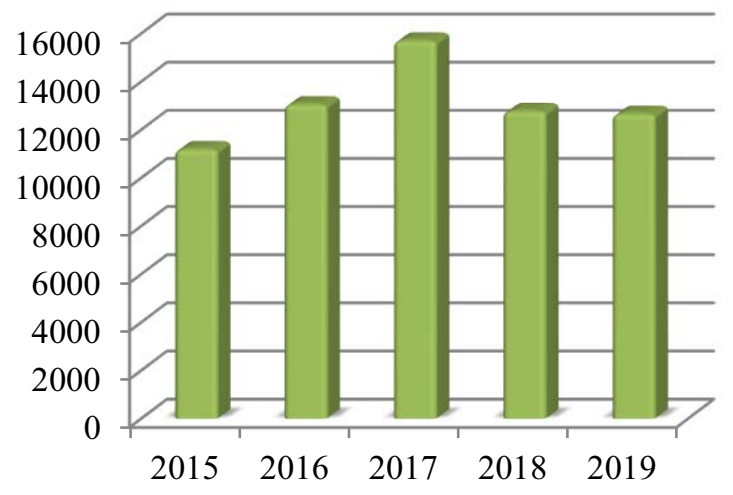

Fig. 2. Production cost dynamics of 1 ton of rape in agricultural organizations of Krasnoyarsk Krai for the period of 2015-2019, rub.

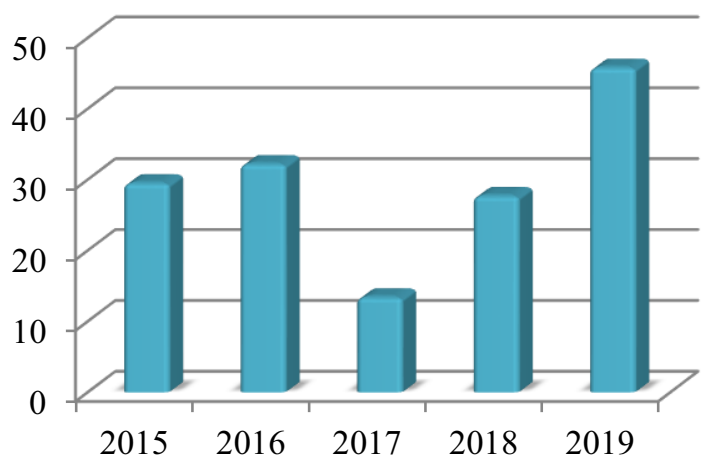

Fig. 3. Dynamics of profitability level of rape production in agricultural organizations of Krasnoyarsk Krai for the period of $2015-2019, \%$ 
Due to competition in the domestic market, cost-effective volumes of edible rapeseed oil sales are difficult, which calls into question the payback of new production. Therefore, we need access to foreign markets with improved quality products produced using safe technologies.

This oil crop has the greatest export potential. Most of the rapeseed oil produced by enterprises in Krasnoyarsk Krai already goes for export. Last year, 91.3 thousand tons of rape oilseeds were sold outside the region.

According to the available data of the Ministry of agriculture of the Russian Federation, Krasnoyarsk Krai mainly exports rape to Mongolia - 14 thousand tons (333.3\% in 2018, +9.8 thousand rub), China -12.6 thousand tons $(120 \%$ by $2018,+2.1$ thousand tons), in 2019 Latvia was added - 3.2 thousand tons.

The plans of regional authorities and entrepreneurs are to develop the oil-and-fat sector of the regional economy through replication of bio-conversion technology of oil crops' cultivation and processing. In addition to the LLC "OPH "Solyanskoye" creamery, it is planned to build a workshop with a capacity of 45 thousand tons of rapeseed oil per year. Within the framework of the national project "International cooperation and export", the state support will given to manufacturers of highly margin products expanding the volume of foreign supplies and their geography. In addition to China, Mongolia, Latvia, it is planned to export of new quality oil-and-fat products to Latvia, Kazakhstan, Kyrgyzstan, Georgia, Azerbaijan.

The main components of export supplies' development of oil-and-fat products of the Krasnoyarsk Krai should be effective schemes of its positioning and promotion in the foreign market, as well as innovative logistics supply chains [8]. This will allow the producers of oil-and-fat products to organize more effective interaction with foreign partners and increase their competitiveness. An increase in the exports' volume of the share of products with a high processing degree and consequently higher added value will be important for the development of the regional economy.

\section{Conclusions}

The project's implementation will allow to create an enterprise for the production and processing of oil crops' seeds with a closed production cycle of products with a high processing degree (edible oil, edible cake, lecithin additives E322, protein composite dry mixtures, extruded granular fodder products) on the territory of the Krasnoyarsk Krai. In addition to high demand on the Russian market, products of deep oil crops' processing will have high export potential [6].

Sufficient availability of own raw materials, minimum transport costs for the raw materials' delivery to the place of processing, modern energy-saving can be noted among the main features and advantages of the Project. These factors provide a lower cost of production, reduce sales costs.

In addition, based the R\&D results obtained during the implementation of the joint project, a scientific and production cluster for the production and processing of oil crops can be created, which will allow to create a number of distributed technological chains and will provide advanced development rates of scientific and scientific-technological developments in the field of seed production, cultivation and processing of Siberian oil crops due to the synergistic effect of interaction of the real economy sector enterprise LLC “OPH Solyanskoye", regional educational and scientific organizations. 


\section{References}

1. Investment certificate of Krasnoyarsk Krai (http://krskinvest.ru/krsk/about/economic/)

2. Federal State Budgetary Institution "Center of Agroanalytics" (https://specagro.ru/news/202002/krasnoyarskiy-kray-naraschivaet-tempyproizvodstva-maslichnykh-kultur)

3. The AIC of Krasnoyarsk Krai in 2019. Website of the Ministry of Agriculture and Trade of Krasnoyarsk Krai (http://krasagro.ru/presentations)

4. Ya.V. Smolnikova, M.A. Yanova, V.L. Bopp, J.A. Olentsova, Assessment of the seed safety indicators from oilseed cruciferous crops in the organization of complex processing technology, Krasnoyarsk Science and Technology City Hall of the Russian Union of Scientific and Engineering Associations Institute of Physics and IOP Publishing Limited, 22061 (2019)

5. Ya.V. Smolnikova, N.A. Velichko, V.L. Bopp, A.V. Kolomeitsev et al. Chemistry of plant raw materials, 191-196 (2021)

6. Feasibility study of the complex project on creation of high-tech production "Creation of complex high-tech production of vegetable oil raw materials and products its processing in the conditions of Siberia." Contract No. 43/20-17 dated 15.04.2018 (LLC "OPH Solyanskoye" and FSBEI of HE Krasnoyarsk SAU) and No. 074-11-2018-016 dated 29.05.2018 (Ministry of Education and LLC "OPH Solyanskoye")

7. N.I. Pyzhikova, K.V. Chepeleva, P.G. Shvalov, International Scientific and Practical Conference "From Inertia to Develop: Research and Innovation Support to Agriculture”, IDSISA 2020, 05009 (2020)

8. N.I. Pyzhikova, K.V. Chepeleva, Zh.N. Smeleva, International scientific conference "far east con" (iscfec 2020), 2214-2225 (2019) 